Original Research Paper

\title{
Analyze the Significance of Age and Height on the Physical and Chemical Properties of Ethiopian Giant Timber Bamboo
}

\author{
${ }^{1 *}$ Yalew Dessalegn, ${ }^{1}$ Balkeshwar Singh and ${ }^{3}$ Aart W. van Vuure \\ ${ }^{1}$ Department of Mechanical Design and Manufacturing Engineering, \\ Mechanical, Adama Science and Technology University, Ethiopia \\ ${ }^{3}$ Department of Materials Engineering; Campus Groep T, \\ Composite Materials Group and Reas Vesaliusstraat 13, 3000 Leuven, Belgium
}

\author{
Article history \\ Received: 23-11-2020 \\ Revised: $28-12-2020$ \\ Accepted: 30-12-2020 \\ Corresponding Author: \\ Yalew Dessalegn \\ Department of Mechanical \\ Design and Manufacturing \\ Engineering, Adama Science \\ and Technology University, \\ Adama City, Ethiopia \\ Email: yalewdesu@yahoo.com
}

\begin{abstract}
This research aims to examine the properties of culm based on the factors of age and height for structural and industrial purposes. Aged from 1-3 years old of culm and the height was divided into 3 parts which bottom, middle and top. The properties of Giant Timber bamboo in Ethiopia were not investigated so far from the other research work using age and height factors. 3 Samples of the culm are harvested at each age in the Amhara region at Injibara town, Ethiopia and 6 specimens are prepared for each experimental work. New growth of the bamboo shoot has higher internodes length, internodes diameter, and culm thickness than the previous generates of bamboo shoot. Morphological characteristics of the culm are improved when the ages of culm younger. Moisture contents and shrinkage of culm decrease when the age of culm older, and along culm height goes from the bottom to top. However, oven-dry density, cellulose, and lignin contents increase when the age of culm older and along culm height goes from the bottom to top. Whereas hemicelluloses, extractive and ash contents decrease when the age of culm older and along culm height goes from the bottom to top. Higher moisture contents of culm used to easy extraction of fibers without damage, but it has higher shrinkage in the culm. Whereas higher basic density of culm used for structural and furniture making. Celluloses are used for the biofuel and pulp industry. The lignin used as a binder and improve the structural application of the culm. Whereas hemicelluloses are used in the paper industry.
\end{abstract}

Keywords: Bamboo, Morphological Properties, Physical Properties, Chemical Properties, Age and Height

\section{Introduction}

A bamboo is a group of grass, family which 1600 bamboo species distributed across the world and bamboo is indigenous in Asia, Africa, North and South -America and Oceania. The subfamily of bamboo is categorized into three groups which are Arundinarieae, Bumbuseae, as well as and Olyreae. According to the coverage area of species, from the largest to lowest are Bambuseae, Arundinarieae, as well as, Olyreaa respectively. Arundinarieae founds in the temperate areas, whereas Bambuseae founds in the tropical areas (Banik, 2015a).

Giant timber bamboo is the common name of Bambusa oldhamii that is the greatest growth performance survival, density and basal area in the world bamboo species. The density, survival rate and the apparent basal area of Bambusa oldhamii were 1731 culms per hectare, $97.9 \%$ and $27.56 \mathrm{~m}^{2} \mathrm{ha}^{-1}$ respectively. The height, internode length and diameter of the Bambusa oldhamii had reached $170-20 \mathrm{~m}, 20-35$ and $10 \mathrm{~cm}$ respectively. Giant Timber bamboo is introduced in Ethiopia, which synonyms with bambisa oldhamii, Lelebaoldhamii, Sinocalamus oldhamii, Dendrocalamop sisoldhamii, Bambusa atrovirens, Dendrocalamop sisatrovirens (Sanquetta et al., 2015; Mulatu et al., 2016).

Bambusa oldhamii required annual average temperatures of $18-20^{\circ} \mathrm{C}$, annual precipitation of more than $1400 \mathrm{~mm}$ and planted in the river banks under 200$300 \mathrm{~m}$ above sea level (Hua and Ping.).

In Ethiopia, research on bamboo management and utilization were scarce. Identified constraints or lack of awareness about the resource, scanty technologies/scientific knowledge, lack/absence of strong policy frameworks and 
institutional set-up and depletion of the resource base. Major opportunities where the existing national and international interest in the appropriate utilization and development of bamboo (Kindu and Mulatu, 2016). Bamboo resources in Ethiopia were restricted by challenges such as lack of product quality, trained manpower, training and technology, capital, working and selling the place, market linkage, support service, organizational, attitudinal and bamboo resource-related challenges (Kebede, 2018).

Nowadays, Bamboo in Ethiopia is limited to traditional applications like house construction, fencing, fodder, household furniture and utensils and firewood (Gebrekidan et al., 2018). Moreover, it has barriers remain to mainstream bamboo construction. Therefore, further research was needed to (1) encourages government, institutional and policy support and integration with the private sector, (2) integrate bamboo with local building materials and promote a broader range of bamboo construction projects, (3) prepare the bamboo building codes and construction product standards and (4) assess resource management and water requirements of supplying bamboo on an industrial scale construction (Paudel, 2011).

Utilization and processing of bamboo culm were influenced by the type of bamboo species, culm locations, nodes or internodes, harvesting seasons (at the end of the rainy season it is much higher moisture contents than at the end of the dry season), bamboo culm age (young culm has a higher moisture content than a mature one), as well as, humidity and dryness of the environment during the growth and harvesting of bamboo (Yu, 2008).

Long segmented stems are known as culms which are existed many hinges known as nodes, with hollow culms joint one the other. Long Unidirectional (UD) fibers exist along within the culm of the internodes and are discontinued at the nodes. Long unidirectional fibers are used for the production of fiber reinforcement composite products. Since Giant Timber bamboo is not indigenous to Ethiopia, most of the species are examined from their continents where it is indigenous (Kalali et al., 2019).

However, in the current research, the morphological, physical and chemical properties of the species in Ethiopia are investigated based on ages and height. The sizes of the bamboo culm are depending upon their species and environmental conditions. Some of the species grow less than $0.5 \mathrm{~m}$, while other species can grow over $30 \mathrm{~m}$, with some species even growing up to $40 \mathrm{~m}$ (Banik, 2015b). The internodes length, internodes diameter and culm wall thickness varied along the culm height go from the bottom to top which internodes diameter and cum wall thickness reduce, but internodes length increase up to middle parts, then decrease. Benton (2015) reported that the relationship between the number of internodes with Internodal length, internodes diameter and culm wall thickness is assessed in different bamboo species. The intermodal lengths are important as it determines the maximum length of the fibers that extracted. The maximum length of fiber is determined by the length of the internodes, but the volume of extracting fibers is determined by the intermodal diameter and culm wall thickness.

Generally, intermodal diameters and culm wall thicknesses are increased around the bottom parts and reducing goes to the top parts.

The dimension of bamboo culm is determined by the age, which newly planted bamboo culm producing a smaller size of the culm. when the new shoots of culm generate, they have attained a maximum culm diameter, internodes length and culm wall thickness. The current research that bamboo plants were planted more than 20 years ago, so that matured enough to characterize their properties. The common age of maturity period of the culm is 2-3 years old. The ages of the culm are influenced by the morphological properties, physical and chemical properties which determined the application area like furniture making, structure working, fibers board production, paper industry, biofuel production and laminated board production (Banik, 2015a). The ages of the bamboo have a negative influence on the moisture contents (Wang et al., 2015).

The moisture contents are higher at the end of the rainy season and lowest at the end of the dry season. The yield of fibers, modulus of elasticity and strength improve when the moisture contents of the bamboo increase. Moreover, the higher moisture contents are used to easily isolate the fibers from the parenchyma, as well as extract a higher amount of bamboo fibers without any damage (Banik, 2015b). The moisture contents vary with the age, species, along the culm length, across the culm wall, environmental condition and harvesting season (INBAR, 1996). Basic density increase when the ages of bamboo older, along with culm length from bottom to top, as well as, across the culm wall from inner to outer parts (Chaowana, 2013).

The basic density has more influence on compressive strength, as well as, modulus of rupture than other mechanical properties (Correal and Arbeláez, 2010). Shrinkage of culm along the height is very low which is favorable properties of bamboo fiber-reinforced composite products. Hence, bamboo has more dimensional stability than wood (Chaowana, 2013). Tangential shrinkage in culm is about $30-50 \%$ less than radial shrinkage, but longitudinal shrinkage is insignificant compared to tangential and radial shrinkage (Azadeh and Ghavami, 2018). Dimensional stability of culm higher when the lower difference between tangential and radial shrinkage (Anokye et al., 2014). 
The main chemical constituents of bamboo are cellulose, hemicelluloses, as well as, lignin. Cellulose contents used to improve the strength and stiffness of bamboo, whereas lignin is used as a matrix that is used for bonding the fibers. Cell wall forms from celluloses which are arranged in a helical configuration around it (Parameswaran et al., 1976). Chemical compositions vary species, environmental condition, ages, and location along with culm height. However, chemical constituents tend to remain slightly constant when the age of culm matured (Liese, 1985).

\section{Materials and Methods}

\section{Study Area}

Kombolcha found a distance of $13 \mathrm{Km}$ far from the Dessie City in the South Wollo Zone of the Amahara Region it has a latitude and longitude of $11^{\circ} 5^{\prime} \mathrm{N} 39^{\circ} 44^{\prime} \mathrm{E}$ with an elevation between 1842 and $1915 \mathrm{~m}$ above sea level. The annual average high and low temperature of Kombolcha is 25.8 and $11.3^{\circ} \mathrm{C}$ respectively, with annual average rainfall $(\mathrm{mm})$ and annual average relative humidity $(\%)$ is 1,027 and 56 respectively.

\section{Sampling Technique}

The bamboo culm was harvested in February 2019 Kombolcha town in South Woll Zone of Amhara Region, Ethiopia. Three representatives of Giant Timber bamboo (bambusa oldhamii) were harvested in each age of one, two and three years old. The age of bamboo culm was known by experienced field personnel using its color and sheath in the culm. The culm was later subdivided into three parts such as the bottom, middle and top portions based on the criteria of internodes length and outer diameter.

\section{Moisture Content}

6 specimens are prepared from each height at the bottom, middle and top parts evaluate moisture contents. 18 experiments was performed at each age of 1,2 and 3 years old of bamboo culm. The total of 54 experiments were performed to evaluate the moisture contents of culm aged from 1-3 years old.

The samples were weighed in an analytical balance accuracy of $0.001 \mathrm{~g}$ and dried in an oven at $105 \pm 2{ }^{\circ} \mathrm{C}$ for $72 \mathrm{~h}$ until a constant weight was attained, then the moisture content of the samples was calculated according to (ASTM, 2004) as follows:

$M C=\frac{M 1-M 2}{M 2} \times 100 \%$

Where:
$M C \quad=$
The moisture content $(\%)$
$M 1=$
The initial weight of the wet sample $(\mathrm{g})$
$M 2$ =
The weight of the dried sample $(\mathrm{g})$

\section{Basic Density}

18 specimens were prepared from each age of 1,2 and 3 years-old and 6 specimens were prepared from each height at the bottom, middle and top position. Each bamboo specimen was prepared for the size of $25 \times 25 \mathrm{~mm} \times \mathrm{t}$. Basic density was determined based on oven-dry weight and green volume. The specimens are weighed in analytical balance before oven-dried. Then, the specimens were oven-dried for $72 \mathrm{~h}$ at $105 \pm 2{ }^{\circ} \mathrm{C}$ until a constant weight was attained. Then, the specimens were weighed in an analytical balance after oven-dried. The green volume of the specimen was measured using digital vernier calipers (Koman and Feher, 2015) reported that basic density was calculated according to the following formula:

$$
B D=\frac{O D W(K g)}{G V\left(m^{3}\right)}
$$

Where:

$$
\begin{aligned}
& B D=\text { Basic Density }\left(\mathrm{Kg} / \mathrm{m}^{3}\right) \\
& O D W=\text { Oven Dry Weight }(\mathrm{Kg}) \\
& G V=\text { Green Volume }\left(\mathrm{m}^{3}\right)
\end{aligned}
$$

\section{Shrinkage in Wall Thickness}

6 specimens are prepared from each height at the bottom, middle and top parts. At each age of 1, 2 and 3 years-old. 18 Experiments are performed to evaluate shrinkage in wall thickness at each age of the culm. Each specimen was prepared in the size of $20 \times 20 \mathrm{~mm} \times \mathrm{t}$. Shrinkage in wall thickness was determined based on the green dimension and oven-dry dimension that was before and after oven dried in the oven respectively. The specimens were oven-dried for $72 \mathrm{~h}$ at $105 \pm 2^{\circ} \mathrm{C}$ until a constant weight was attained. Then, the size of the specimens measured using digital vernier calipers.

ASTM (1997) stated that shrinkage in wall thickness calculated according to the following formula:

$S H C M=\frac{G D-O D D}{G D} \times 100 \%$

Where:

SHCM = Shrinkage in Culm $(\%)$

$G D=$ Green Dimension $(\mathrm{mm})$

$O D D=$ Oven Dry Dimension $(\mathrm{mm})$ 
Table 1: Age determination of Bambusa oldhamii bamboo

\begin{tabular}{|c|c|c|c|}
\hline \multirow[b]{2}{*}{ Morphological features } & \multicolumn{3}{|l|}{ Bamboo age } \\
\hline & $<1$ year & 1-2 year & $>2$ year \\
\hline Internode color & $\begin{array}{l}\text { White flour is distributed on the } \\
\text { surface of the bamboo Culm }\end{array}$ & Gets Light green & Gets darker green \\
\hline Culm sheaths & $\begin{array}{l}\text { More than half of the bamboo } \\
\text { culm covered with a sheath }\end{array}$ & $\begin{array}{l}\text { The culm sheath begins to } \\
\text { fall until none are left }\end{array}$ & All of the culm sheaths \\
\hline
\end{tabular}

Table 2: Criteria setting for the division of bamboo culm along with the height

\begin{tabular}{lll}
\hline Age & Position & Criteria \\
\hline 1 year & Bottom & Wall thickness $>9.25 \mathrm{~mm}$ \\
& Middle & Between bottom and top \\
& Top & Outer diameter $<104 \mathrm{~mm}$ \\
2 year & Bottom & Wall thickness $>8.35 \mathrm{~mm}$ \\
& Middle & Between bottom and top \\
& Top & Outer diameter $<74 \mathrm{~mm}$ \\
3 year & Bottom & Wall thickness $>7.15 \mathrm{~mm}$ \\
& Middle & Between bottom and top \\
& Top & Outer diameter $<62 \mathrm{~mm}$ \\
\hline
\end{tabular}

\section{Age of Culm Determination Method}

As presented in Table 1, internode color and sheaths are used to determine the ages of the Giant Timber bamboo. At an early age, white flour with culm sheaths has covered the whole of the culm, whereas at a young age, light green with some culm sheaths are covered in the culm and the older and older age, dark and darker green without culm sheaths are covered in the culm.

\section{Culm Height Determination Methods}

As presented in Table 2, criteria set for the division of the Giant Timber Bamboo culm along the height used bottom criteria in the culm wall thickness and top criteria in the outer diameter. The middle position is between the bottom and top positions. Between the ages of 1, 2 and 3 years-old, bottom criteria in the culm wall thickness are greater than $9.25,8.35$ and $7.15 \mathrm{~mm}$, moreover, the top criteria in the culm diameter are less than 104, 74 and $62 \mathrm{~mm}$ respectively.

\section{Statistical Analysis}

Significant of the main factor of ages and heights were analyzed using Analysis of Variance (ANOVA) with stata. version 12 software.

Investigation of the variance was applied to decide that the main factors were significant or insignificant to a difference in means.

\section{Results}

\section{Morphological Characteristics of the Culm}

As shows in the Table 3, the age of 1, 2 and 3 yearsold of Giant Timber bamboo has an average clump length of $12.00,10.07$ and $10.29 \mathrm{~m}$, number of internodes per clump of 39, 35 and 32, range of internodes length of 22.3-34.6, 25.0-32.9 and 29.2-34.4 cm, culm diameter of 75.04-125.67, 47.66-96.05 and 33.01-89.11 mm, as well as, culms wall thickness of 4.47-13.98, 4.79-12.59 and 3.98-9.71 mm respectively. Giant Timber bamboo has properties like other bamboo species tapers from the base towards the tip and culm diameter, Internodes culm length, as well as wall thickness decrease when the number of internodes increase.

The main factor of culm age significantly $(\mathrm{P}<0.05)$ value influenced all parameters measured such as moisture content, basic density and shrinkage of wall thickness, whereas along culm height was not statistically significant at $(\mathrm{P}<0.05)$ value on moisture content, basic density and shrinkage of culm thickness. Pairwise comparison of age and height in the turkey method are presented in Tables 4 and 5. The factor of age between 2 Vs 1 and 3 Vs 1 are statistically significant at $(\mathrm{P}<0.05)$. However, the factor of age between $3 \mathrm{Vs} 2$ is not statistically significant at $(\mathrm{P}<0.05)$. The pairwise comparison of the factor of height is not statistically significant at $(\mathrm{P}<0.05)$.

\section{Physical Characteristics of the Culm}

\section{Moisture Content}

The mean moisture content (\%) of along with the culm height at the bottom, middle and top are 143.067, 121.767 and 101.933, whereas, at the age of 1, 2 and 3 years old are $159.167,139.0667$ and 68.533 respectively, as presented in Fig. 1.

In the present results, the moisture content decrease when the age of the culm older and along culm height goes from the bottom to top.

The main factor of age on the moisture content was a statistically significant difference at $(\mathrm{P}<0.05)$, whereas along the culm height was not a statistically significant difference at $(\mathrm{P}<0.05)$, as presented in Tables 6 and 7 .

\section{Basic Density of the Culm}

As indicated in Fig. 2: The mean basic density $\left(\mathrm{Kg} / \mathrm{m}^{3}\right)$ of Giant Timber bamboo at the ages of 1, 2 and 3 yearsold are 596.7, 745.4 and 825.7 respectively. The basic density increase when the ages of the culm older, as well as, along the culm height goes from bottom to top. 
Yalew Dessalegn et al. / American Journal of Engineering and Applied Sciences 2021, 14 (2): 185.197 DOI: 10.3844/ajeassp.2021.185.197

Table 3: Morphological characteristics of Giant Timber bamboo

\begin{tabular}{|c|c|c|c|c|}
\hline \multirow[b]{2}{*}{ Morphological features } & \multirow[b]{2}{*}{ Position } & \multicolumn{3}{|l|}{ Age } \\
\hline & & 1 year & 2 year & 3 year \\
\hline Average culm length (m) & & 12.00 & 10.07 & 10.29 \\
\hline No. Internode per culm & & 39.00 & 35 & 32.00 \\
\hline \multirow[t]{4}{*}{ Average culm Wall Thickness (mm) } & Bottom & 13.98 & 12.59 & 9.71 \\
\hline & Middle & 7.14 & 6.71 & 6.62 \\
\hline & Top & 4.47 & 4.79 & 3.98 \\
\hline & Mean & 8.53 & 8.03 & 6.77 \\
\hline \multirow[t]{4}{*}{ Average Internode diameter (mm) } & Bottom & 125.67 & 96.05 & 89.11 \\
\hline & Middle & 112.72 & 80.05 & 66.15 \\
\hline & Top & 75.04 & 47.66 & 33.01 \\
\hline & Mean & 104.48 & 74.59 & 62.75 \\
\hline \multirow[t]{4}{*}{ Average Internode length $(\mathrm{cm})$} & Bottom & 34.60 & 25.00 & 34.30 \\
\hline & Middle & 36.30 & 28.60 & 32.30 \\
\hline & Top & 22.30 & 32.90 & 29.20 \\
\hline & Mean & 31.00 & 28.80 & 31.90 \\
\hline \multirow{3}{*}{ Section of Culm length in the height (m) } & B & $0-4.00$ & $0-3.50$ & $0-5.00$ \\
\hline & M & $4.00-8.00$ & $3.50-6.00$ & $5.00-7.00$ \\
\hline & $\mathrm{T}$ & $8.00-12.00$ & $6.00-10.00$ & $7.00-10.00$ \\
\hline
\end{tabular}

Table 4: Pairwise comparison of age in Tukey method

\begin{tabular}{|c|c|c|c|c|c|c|}
\hline \multirow[b]{2}{*}{ Age } & \multirow[b]{2}{*}{ Contrast } & \multirow[b]{2}{*}{ Std. Err. } & \multicolumn{2}{|c|}{ Tukey } & \multicolumn{2}{|l|}{ Tukey } \\
\hline & & & $\mathrm{t}$ & $p>|t|$ & {$[95 \% \mathrm{C}$} & \\
\hline $2 \mathrm{Vs} 1$ & -10.3770 & 2.44617 & -4.24 & 0.029 & -19.095 & -1.65860 \\
\hline $3 \mathrm{Vs} 1$ & -12.4800 & 2.44617 & -5.10 & 0.015 & -21.198 & -3.76190 \\
\hline $3 \mathrm{Vs} 2$ & -2.1033 & 2.44617 & -0.86 & 0.691 & -10.821 & 6.61478 \\
\hline
\end{tabular}

Table 5: Pairwise comparison of height in Tukey method

\begin{tabular}{|c|c|c|c|c|c|c|}
\hline \multirow[b]{2}{*}{ Height } & \multirow[b]{2}{*}{ Contrast } & \multirow[b]{2}{*}{ Std. Err. } & \multicolumn{2}{|c|}{ Tukey } & \multicolumn{2}{|l|}{ Tukey } \\
\hline & & & $\mathrm{t}$ & $\mathrm{p}>|\mathrm{t}|$ & [95\% Conf. Interval] & \\
\hline 2 vs 1 & 3.47000 & 2.44617 & 1.42 & 0.415 & -5.2481 & 12.1881 \\
\hline 3 vs 1 & 7.83334 & 2.44617 & 3.20 & 0.069 & -0.8848 & 16.5514 \\
\hline $3 \mathrm{vs} 2$ & 4.36333 & 2.44617 & 1.78 & 0.285 & -4.3548 & 13.0814 \\
\hline
\end{tabular}

Table 6: ANOVA factor of Age in the response of moisture content

\begin{tabular}{|c|c|c|c|c|c|}
\hline \multicolumn{3}{|c|}{$\begin{array}{l}\text { Number of obs }=54 \\
\text { Root MSE }=21.8372\end{array}$} & \multicolumn{3}{|c|}{$\begin{array}{l}\text { R-squared }=0.8261 \\
\text { Adj R-squared } 0.7682\end{array}$} \\
\hline Source & Partial SS & $\mathrm{df}$ & MS & $\mathrm{F}$ & Prob $>F$ \\
\hline Model & 13593.40 & 2 & 6796.680 & 14.25 & 0.0053 \\
\hline Age & 13593.40 & 2 & 6796.680 & 14.25 & 0.0053 \\
\hline Residual & 2861.18 & 6 & 476.863 & & \\
\hline Total & 16454.50 & 8 & 2056.820 & & \\
\hline
\end{tabular}

Table 7: ANOVA factor of Height in the response of moisture content

\begin{tabular}{|c|c|c|c|c|c|}
\hline \multicolumn{3}{|c|}{$\begin{array}{l}\text { Number of obs }=54 \\
\text { Root MSE }=48.1587\end{array}$} & \multicolumn{3}{|c|}{$\begin{array}{l}\text { R-squared =0.1543 } \\
\text { Adj R-squared = -0.1276 }\end{array}$} \\
\hline Source & Partial SS & $\mathrm{df}$ & MS & $\mathrm{F}$ & Prob $>F$ \\
\hline Model & 2539.0 & 2 & 1269.50 & 0.55 & 0.6048 \\
\hline Height & 2539.0 & 2 & 1269.50 & 0.55 & 0.6048 \\
\hline Residual & 13915.5 & 6 & 2319.26 & & \\
\hline Total & 16454.5 & 8 & 2056.82 & & \\
\hline
\end{tabular}


Table 8: ANOVA factor of Age in the response of basic density

Number of obs $=9$

Root MSE $=0.140199$

\begin{tabular}{lllll} 
Source & Partial SS & df & MS & F \\
\hline Model & 0.40916 & 2 & 0.20458 & 10.41 \\
Age & 0.40916 & 2 & 0.20458 & 10.41 \\
Residual & 0.11793 & 6 & 0.01966 & 0.0112 \\
Total & 0.52710 & 8 & 0.06589 & F \\
\hline
\end{tabular}

Table 9: ANOVA factor of Height in the response of basic density

\begin{tabular}{|c|c|c|c|c|c|}
\hline \multicolumn{3}{|c|}{$\begin{array}{l}\text { Number of obs }=9 \\
\text { Root MSE }=0.287992\end{array}$} & \multicolumn{3}{|c|}{$\begin{array}{l}\text { R-squared }=0.0559 \\
\text { Adj R-squared }=-0.2588\end{array}$} \\
\hline Source & Partial SS & $\mathrm{df}$ & MS & $\mathrm{F}$ & Prob $>F$ \\
\hline Model & 0.02946 & 2 & 0.01473 & 0.18 & 0.8415 \\
\hline Height & 0.02946 & 2 & 0.01473 & 0.18 & 0.8415 \\
\hline Residual & 0.49764 & 6 & 0.08294 & & \\
\hline Total & 0.52710 & 8 & 0.06589 & & \\
\hline
\end{tabular}

Table 10: ANOVA factor of Age in the response in Shrinkage of wall thickness

\begin{tabular}{|c|c|c|c|c|c|}
\hline \multicolumn{3}{|c|}{$\begin{array}{l}\text { Number of obs }=54 \\
\text { Root MSE }=4.62499\end{array}$} & \multicolumn{3}{|c|}{$\begin{array}{l}\text { R-squared }=0.6761 \\
\text { Adj R-squared }=0.5681\end{array}$} \\
\hline Source & Partial SS & df & MS & $\mathrm{F}$ & Prob $>F$ \\
\hline Model & 267.850 & 2 & 133.925 & 6.26 & 0.034 \\
\hline Age & 267.850 & 2 & 133.925 & 6.26 & 0.034 \\
\hline Residual & 128.343 & 6 & 21.3905 & & \\
\hline Total & 396.193 & 8 & 49.5241 & & \\
\hline
\end{tabular}

Table 11: ANOVA factor of height in the response in Shrinkage of wall thickness

\begin{tabular}{|c|c|c|c|c|c|}
\hline \multicolumn{3}{|c|}{$\begin{array}{l}\text { Number of obs }=54 \\
\text { Root MSE }=7.11515\end{array}$} & \multicolumn{3}{|c|}{$\begin{array}{l}\text { R-squared }=0.2333 \\
\text { Adj R-squared }=-0.0222\end{array}$} \\
\hline Source & Partial SS & $\mathrm{DF}$ & MS & $\mathrm{F}$ & Prob $>F$ \\
\hline Model & 92.4407 & 2 & 46.2203 & 0.91 & 0.4506 \\
\hline Height & 92.4407 & 2 & 46.2203 & 0.91 & 0.4506 \\
\hline Residual & 303.752 & 6 & 50.6253 & & \\
\hline Total & 396.193 & 8 & 49.5241 & & \\
\hline
\end{tabular}

Table 12: Chemical constituents of giant timber bamboo

\begin{tabular}{lllllll}
\hline Age & Location & $\begin{array}{l}\text { Ash } \\
(\mathrm{SD}) \%\end{array}$ & $\begin{array}{l}\text { Extractives } \\
(\mathrm{SD}) \%\end{array}$ & $\begin{array}{l}\text { Hemicelluloses } \\
(\text { SD)\% }\end{array}$ & $\begin{array}{l}\text { Cellulose } \\
(\text { SD }) \%\end{array}$ & $\begin{array}{l}\text { Lignin } \\
(\mathrm{SD}) \%\end{array}$ \\
\hline 1 & Bottom & $2.49(0.15)$ & $11.43(0.68)$ & $23.59(1.73)$ & $43.25(2.65)$ & $19.29(1.13)$ \\
& Middle & $2.74(0.18)$ & $11.29(0.53)$ & $23.65(1.69)$ & $43.44(2.48)$ & $19.42(1.21)$ \\
& Top & $2.89(0.17)$ & $10.15(0.56)$ & $23.89(1.92)$ & $43.75(2.58)$ & $19.57(1.53)$ \\
& Mean & $2.71(0.17)$ & $10.96(0.59)$ & $23.71(1.78)$ & $43.48(2.57)$ & $19.43(1.29)$ \\
2 & Bottom & $1.88(0.07)$ & $10.69(0.64)$ & $22.06(1.23)$ & $45.34(2.75)$ & $20.26(1.46)$ \\
& Middle & $2.32(0.13)$ & $10.47(0.61)$ & $22.16(1.35)$ & $44.55(2.82)$ & $21.21(1.61)$ \\
& Top & $2.59(0.16)$ & $10.15(0.67)$ & $22.75(1.45)$ & $43.15(2.78)$ & $21.73(1.82)$ \\
3 & Mean & $2.26(0.12)$ & $10.44(0.64)$ & $22.32(1.34)$ & $44.35(2.78)$ & $21.07(1.63)$ \\
& Bottom & $1.53(0.08)$ & $7.94(0.39)$ & $19.31(1.15)$ & $48.73(3.06)$ & $22.29(1.89)$ \\
& Middle & $1.8(0.05)$ & $7.38(0.36)$ & $19.52(1.18)$ & $49.02(3.11)$ & $22.37(1.94)$ \\
& Top & $2.27(0.14)$ & $7.02(0.34)$ & $19.74(1.21)$ & $49.23(3.09)$ & $22.59(1.97)$ \\
& Mean & $1.87(0.09)$ & $7.45(0.36)$ & $19.52(1.18)$ & $48.99(3.08)$ & $22.42(1.93)$ \\
\hline
\end{tabular}


The main factor of age on the basic density was a statistically significant difference at $(\mathrm{P}<0.05)$, whereas, along with culm height was not a statistically significant difference at $(\mathrm{P}<0.05)$, as presented in Tables 8 and 9.

\section{Shrinkage in Culm Wall Thickness}

The average shrinkage in wall thickness (\%) along with culm height have registered at the bottom 15.683, at the middle 13.59 and the top 12.327 respectively, whereas the average shrinkage (\%) in wall thickness at the ages of 1,2 and 3 years-old have registered 17.077, 13.3 and 12.223 respectively, as presented in Fig. 3.

The main factor of age on the percentage of shrinkage in wall thickness was a statistically significant difference at $(\mathrm{P}<0.05)$, whereas along with culm height was not a statistically significant difference at $(\mathrm{P}<0.05)$, as presented in Tables 10 and 11.

\section{Chemical Composition of the Culm}

Chemical constituents of the bamboo culms have influenced on the application area like structural, construction, biofuel and fibers board production. The main chemical constituents of bamboo culms are Cellulose, hemicelluloses, lignin and extractives.

Bamboo strips are cut into small pieces using scissors, then grind using higher duty coffee grinder mill in powder form. The powder is sieved in the seive size of 425 and $375 \mu \mathrm{m}$. The sample size of the particles are passed through in sieve size of $425 \mu \mathrm{m}$ and lay down on sieve size of $375 \mu \mathrm{m}$. The current studies have applied the methods of gravimetric methods to determine the chemical constituents of the culm. Acetone, $\mathrm{NaOH}$ and $\mathrm{H}_{2} \mathrm{SO}_{4}$ are utilized for the determination of extractive, hemicelluloses and lignin contents respectively. The gravimetric methods are selected for chemical constituent analysis in considering economically suitable for developing countries because of cheap and mostly available on the shelf (Adeeyo et al., 2015).

\section{Cellulose Contents}

As shown in the Table 12, the average cellulose contents $(\%)$ of Giant Timber bamboo at the ages of 1, 2 and 3 years-old are 43.48, 44.35 and 48.99 respectively. The cellulose contents increase when the ages of the bamboo culm older. Whereas the cellulose contents increases when goes along culm height from the bottom to top parts at the ages of 1 and 3 years old, but decrease when goes along culm height from the bottom to top parts at the ages of 2 years-old.

\section{Hemicelluloses Content}

The hemicelluloses contents (\%) of Giant Timber bamboo, depending upon ages and heights are presented in Table 12. At the ages of 1, 2 and 3 years-old of average hemicelluloses contents (\%) are 23.71, 22.32 and 19.52 respectively. The hemicelluloses contents decrease when the ages of the culm older. Whereas, the hemicelluloses content increases when goes along culm height from the bottom to top parts.

\section{Lignin Contents}

As shown in Table 12, the average lignin contents of Giant Timber bamboo at the ages of 1, 2 and 3 years-old are $19.43,21.07$ and $22.42 \%$ respectively. The lignin contents increase when the ages of the culm older, as well as along culm height from the bottom to top parts.

\section{Extractive Contents}

The effect of ages and height on the extractive contents are presented in Table 12. The average of extractive contents $(\%)$ of Giant Timber bamboo at the ages of 1,2 and 3 years old are $10.96,10.44$ and 7.45 respectively. The average percentage of extractive contents decreases when the ages of the culm older, as well as go along culm height from the bottom to top parts.

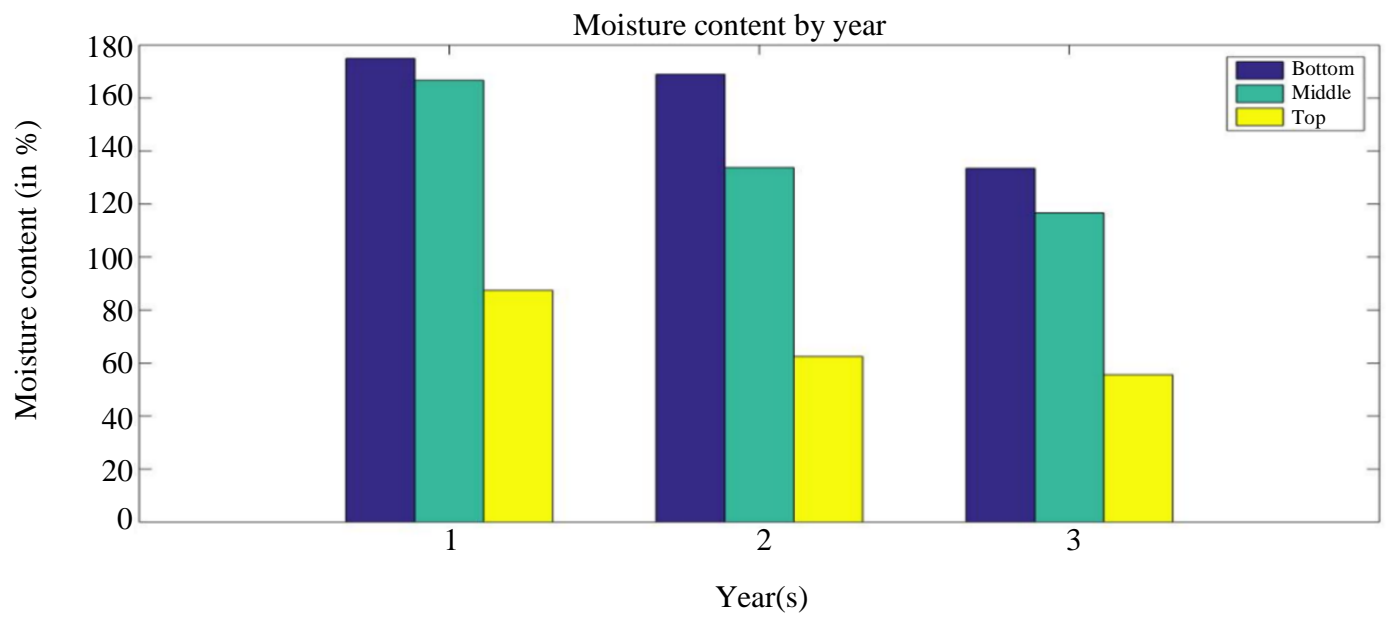

Fig. 1: Moisture content a long culm height aged from 1-3 years-old Giant Timber bamboo 


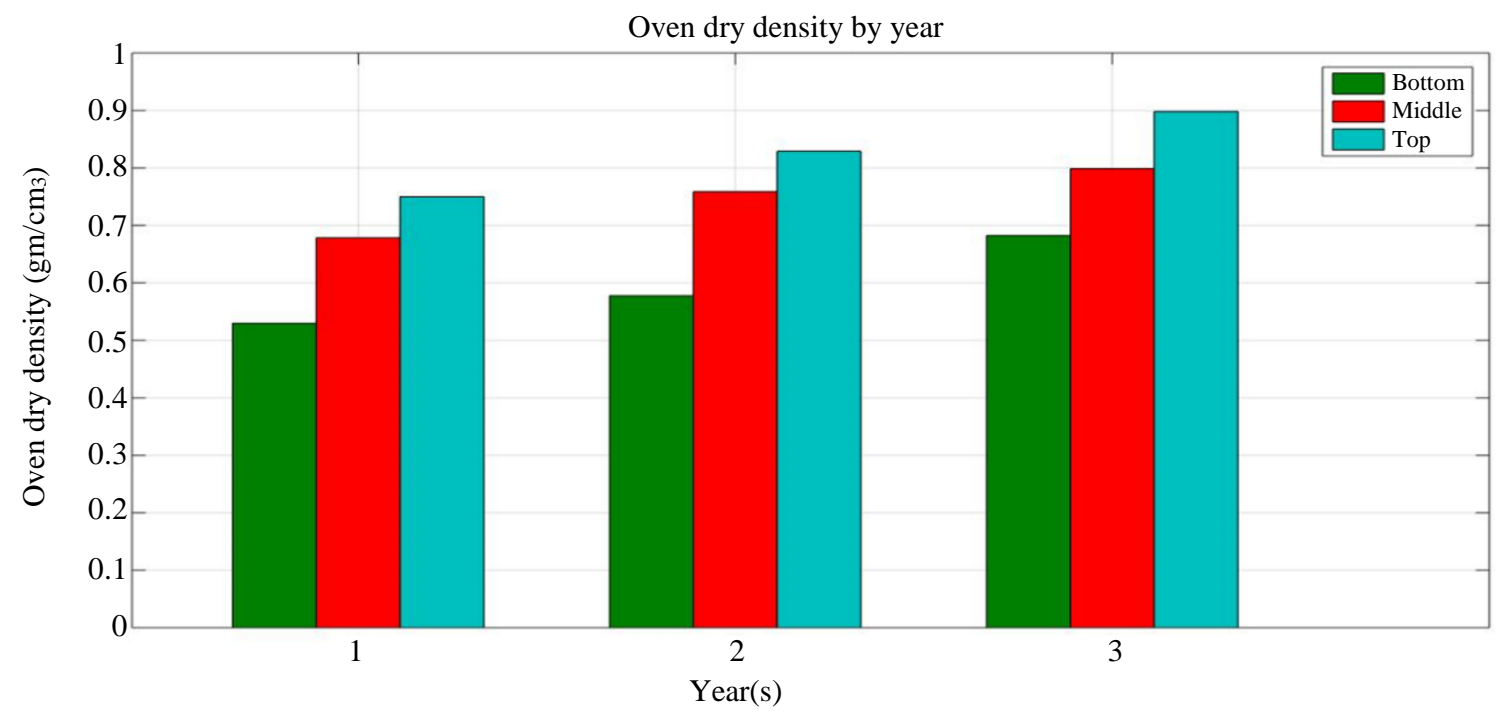

Fig. 2: Basic density of Giant Timber bamboo aged from 1-3 years-old with along culm height

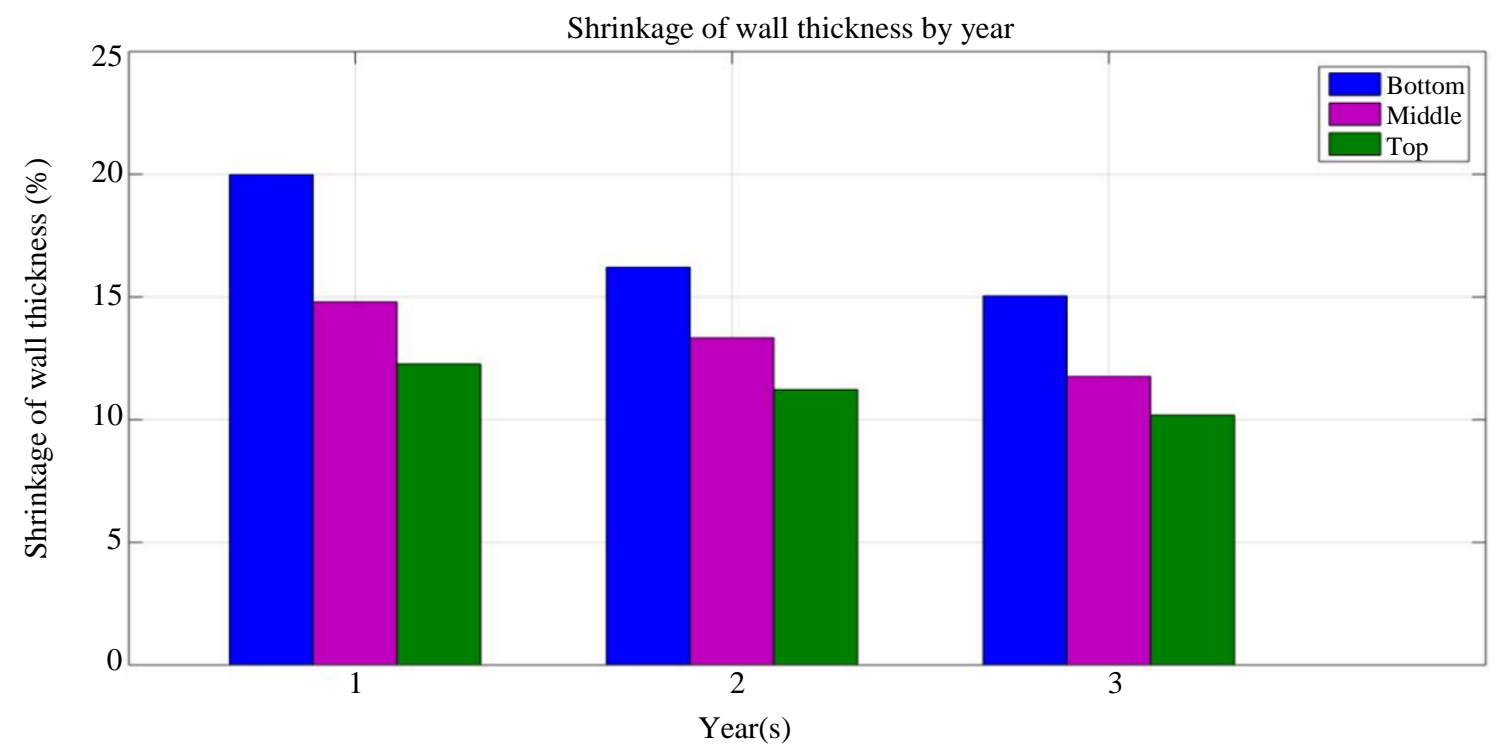

Fig. 3: Shrinkage in culm wall thickness along culm height and aged from 1-3 years-old

\section{Ash Contents}

As shown in Table 12, the average ash contents (\%) of Giant Timber bamboo at the ages of 1, 2 and 3 years-old are $2.71,2.26$ and 1.87 respectively. The ash contents decrease when the ages of the culm older, as well as along culm height goes from the bottom to top parts.

\section{Discussion}

The culm length (m) of Bambusa Blumeana at the ages of 1, 2 and 3 years old are 18.90, 18.29 and 17.38, internodes length $(\mathrm{cm})$ are 18.3-33.4, 25.1-34.1 and 29.9-35.0, internodes diameter $(\mathrm{cm})$ are 7.7-8.2, 7.3-
8.2 and 8.1-8.7, as well as, culm wall thickness $(\mathrm{cm})$ are $0.71-1.14,0.72-1.10$ and $0.82-1.46$ respectively.

The current results of Giant Timber bamboo have higher internodes length, number of internodes, internodes diameter and wall thickness, but the lower culm length than the previous studies of Bambusa Blumeana. Therefore, the Giant Timber bamboo has good morphological properties which are utilized in the application area of building house, industrial purpose and furniture making (Mohmod et al., 2016a).

Reported Dendrocalamus asper was culm height of 20-30 m, culm diameter of 7.0-10.0 cm, wall thickness of 11-20 $\mathrm{mm}$ and internodes length of $20-45 \mathrm{~cm}$, 
Dendrocalamus giganteus Wallich ex Munro was culm height of 30-36 m, culm diameter of $16-30 \mathrm{~cm}$, wall thickness of 2.5-3.5 cm and internodes length of 20-70 $\mathrm{cm}$, Dendrocalamus hamiltonii was culm height of $12-25 \mathrm{~m}$, culm diameter of 9-19 cm, wall thickness of 0.8-1.2 cm and internodes length of 30-50 cm, Dendrocalamus longispathus was culm height of 10-18 m, culm diameter of 4-10 cm, wall thickness of $0.2-1.8 \mathrm{~cm}$ and internodes length of 25$65 \mathrm{~cm}$ and Dendrocalamus membranaceus Munro was culm height of $18-25 \mathrm{~m}$, culm diameter of $8-11 \mathrm{~cm}$, wall thickness of $0.8-1.6 \mathrm{~cm}$ and internodes length of 30-50 $\mathrm{cm}$ respectively (Banik 2015a).

The range of internodes length of Gigantochloa scortechinii bamboo is $32.3-49.5 \mathrm{~cm}$, internodes diameter $10.5-17.8 \mathrm{~cm}$ and culm wall thickness $6-8.5 \mathrm{~mm}$. Similar findings were found with the current results of Giant Timber bamboo (Hisham et al., 2006).

Internodal length, wall thickness and culm diameter of Moso bamboo was 250, 10 and $90 \mathrm{~mm}$. Whereas, Guadua bamboo are 330, 21 and $120 \mathrm{~mm}$ respectively. The Giant Timber bamboo has higher internodal length, wall thickness and culm diameter than Moso and Guadua bamboo (Pozo Morales et al., 2017).

The moisture contents of Yushanina Alpina at the ages of $2(120.3 \%)$ lower and $3(100.5 \%)$ higher than the current results of Giant Timber bamboo at the ages of 1,2 and 3 years-old (Gebremariam and Assefa, 2018).

The moisture content of Bambusa Blumeana bamboo at the ages of 1 (79.3-97.0\%) lower, 2 (57.3-79.6\%) lower and $3(57.5-79.6 \%)$ higher than the current results of Giant Timber bamboo at the ages of 1,2 and 3 years-old (Mohmod et al., 2016b).

The moisture contents of Bambusa vulgaris var. vulgaris at the ages of $1(49.13 \%)$ lower, $2(40.07 \%)$ lower and 3 (39.73\%) lower, Bambusa vulgaris var. striata ages of 1 (29.68\%) lower, 2 (29.43\%) lower, 3 (27.82\%) lower, Bambusa balcooa at the ages of $1(56.86 \%)$ lower, 2 $(51.46 \%)$ lower and $3(48.35 \%)$ lower, Bambusa tulda at the ages of $1(42.93 \%)$ lower, $2(48.76 \%)$ lower and 3 (38.60\%) lower, Bambusa polymorpha at the ages of 1 (68.14\%) lower, 2 (62.48\%) lower and $3(56.85 \%)$ lower, Dendrocalamus strictus at the ages of $1(49.02 \%)$ lower, $2(48.76 \%)$ lower and $3(38.60 \%)$ lower, as well as, Bambusa bambos at the ages of $1(56.19 \%)$ lower, 2 $(49.64 \%)$ lower and $3(41.34 \%)$ lower than the current results of Giant Timber bamboo at the ages of 1, 2 and 3 years old respectively (Thirunirai Selvan et al., 2017).

The moisture contents of Bambusa Balcooa, Bambusa Tulda, Bambusa Salarkhanii and Melocanna Baccifera bamboo decreased along with the culm height goes from the bottom to top parts. Whereas, their ages of 2, 3 and 4 years-old were a little effect on the moisture content. However, their findings of moisture contents were low compared to the current results of Giant Timber bamboo (Kamruzzaman et al., 2018).
The moisture contents of Bambusa blumeana at the ages of $1(105.92 \%)$ lower, $2(81.33 \%)$ lower and 3 (94.80\%) higher, Bamusa Vulgaris var ages of 1 $(224.96 \%)$ higher, 2 (86.66\%) lower and $3(89.95 \%)$ higher, as well as, Gigantochlo scortechinii at the ages of $1(108.58 \%)$ lower, $2(93.21 \%)$ lower and $3(90.57 \%)$ higher than the current results of Giant Timber bamboo at the ages of 1, 2 and 3 years old (Mohmod et al., 2016a).

The basic density of Bambusa vulgaris var. vulgaris at the ages of $1\left(410.5 \mathrm{Kg} / \mathrm{m}^{3}\right)$ lower, $2\left(426.4 \mathrm{Kg} / \mathrm{m}^{3}\right)$ lower and $3\left(441.8 \mathrm{Kg} / \mathrm{m}^{3}\right)$ lower, Bambusa vulgaris var. striata at the ages of $1\left(390.0 \mathrm{Kg} / \mathrm{m}^{3}\right)$ lower, $2\left(410.0 \mathrm{Kg} / \mathrm{m}^{3}\right)$ lower and $3\left(435.0 \mathrm{Kg} / \mathrm{m}^{3}\right)$ lower, Bambusa balcooa at the ages of $1\left(428.0 \mathrm{Kg} / \mathrm{m}^{3}\right)$ lower, $2\left(442.0 \mathrm{Kg} / \mathrm{m}^{3}\right)$ lower and $3\left(466.0 \mathrm{Kg} / \mathrm{m}^{3}\right)$ lower, Bambusa tulda at the ages of 1 $\left(431.2 \mathrm{Kg} / \mathrm{m}^{3}\right)$ lower, $2\left(446.8 \mathrm{Kg} / \mathrm{m}^{3}\right)$ lower and $3(468.2$ $\left.\mathrm{Kg} / \mathrm{m}^{3}\right)$ lower, Bambusa polymorpha at the ages of 1 (416.7 $\left.\mathrm{Kg} / \mathrm{m}^{3}\right)$ lower, $2\left(428.4 \mathrm{Kg} / \mathrm{m}^{3}\right)$ lower and $3\left(441.6 \mathrm{Kg} / \mathrm{m}^{3}\right)$ lower, Dendrocalamus strictus at the ages of $1\left(432 .{ }^{3} \mathrm{Kg} / \mathrm{m}^{3}\right)$ lower, $2\left(448.7 \mathrm{Kg} / \mathrm{m}^{3}\right)$ lower and $3(458.0 \mathrm{Kg} / \mathrm{m} 3)$ lower, as well as, Bambusa bambos at the ages of 1 $\left(422.2 \mathrm{Kg} / \mathrm{m}^{3}\right)$ lower, $2\left(438.8 \mathrm{Kg} / \mathrm{m}^{3}\right)$ lower and 3 $\left(450.75 \mathrm{Kg} / \mathrm{m}^{3}\right)$ lower than the current results of Giant Timber bamboo at the ages of 1,2 and 3 years old (Thirunirai Selvan et al., 2017).

Mean basic density $\left(\mathrm{Kg} / \mathrm{m}^{3}\right)$ of Yushania Alpina at the age of $1\left(599.85 \mathrm{Kg} / \mathrm{m}^{3}\right)$ higher, $2\left(652.89 \mathrm{Kg} / \mathrm{m}^{3}\right)$ lower and $3\left(666.85 \mathrm{Kg} / \mathrm{m}^{3}\right)$ lower than the current results of Giant Timber bamboo at the ages of 1,2 and 3 years old (Gebremariam and Assefa, 2018).

The mean basic density of Bambusa blumeana at the ages $1\left(1103 \mathrm{Kg} / \mathrm{m}^{3}\right)$ higher, $2\left(1037 \mathrm{Kg} / \mathrm{m}^{3}\right)$ higher and $3(1000$ $\left.\mathrm{Kg} / \mathrm{m}^{3}\right)$ higher, Bamusa Vulgaris var at the ages of $1(293$ $\left.\mathrm{Kg} / \mathrm{m}^{3}\right)$ lower, $2\left(507 \mathrm{Kg} / \mathrm{m}^{3}\right)$ lower and $3\left(543 \mathrm{Kg} / \mathrm{m}^{3}\right)$ lower, as well as, Gigantochlo scortechinii at the ages of 1 $\left(470 \mathrm{Kg} / \mathrm{m}^{3}\right)$ lower, $2\left(533 \mathrm{Kg} / \mathrm{m}^{3}\right)$ lower and $3\left(557 \mathrm{Kg} / \mathrm{m}^{3}\right)$ lower than the current results of Giant Timber bamboo at the ages of 1, 2 and 3 years old (Mohmod et al., 2016b).

Basic density increased when the age of culm older and goes from bottom to the top along with the culm height (Pozo Morales et al., 2017; Wang et al., 2010).

Mean basic density $\left(\mathrm{Kg} / \mathrm{m}^{3}\right)$ of Gigantochloa levis at the age of $2\left(733 \mathrm{Kg} / \mathrm{m}^{3}\right)$ lower and $4\left(751 \mathrm{Kg} / \mathrm{m}^{3}\right)$ lower, whereas along with culm height at the bottom $\left(696.5 \mathrm{Kg} / \mathrm{m}^{3}\right)$ lower, middle $\left(750.5 \mathrm{Kg} / \mathrm{m}^{3}\right)$ lower and top $\left(758.5 \mathrm{Kg} / \mathrm{m}^{3}\right)$ lower than the current results of Giant Timber bamboo at the ages of 1, 2 and 3 years old and at the bottom, middle and top parts respectively (Sadiku and Bada, 2017).

Basic density of Bambusa balcooa and Bambusa Tulda aged from 2-4 years-old have lower, whereas, melocanna baccifera and Bambusa Salarkhanii aged from 2-4 years old have higher than the current results of Giant timber bamboo aged from 1-3 years old (Kamruzzaman et al., 2008). 
The shrinkage in wall thickness decrease when the age of the culm older and along culm height goes from the bottom to top of Bambusa Blumeana. However, their findings were low shrinkage in wall thickness compared to the current results of Giant Timber bamboo (Mohmod et al., 2016a).

The shrinkage in culm wall thickness of Giant Timber was low compared to the previous results of Gigantochlo Scortechinii (Anwar et al., 2005).

The shrinkage in wall thickness of Gigantochloa levis at the age of $2(7.69 \%)$ lower, $3(5.21 \%)$ lower and $4(5.60 \%)$ lower than the current results of Giant Timber bamboo aged from 1-3 years old (Sadiku and Bada, 2017).

The mean percentage of shrinkage in the wall thickness decrease from bottom to the top along with the culm height of B. balcooa, B. tulda, B. salarkhanii and Melocanna baccifera. Ages of 4 years old has not a significant effect on the shrinkage in wall thickness. Similar findings were obtained with the current results of Giant Timber bamboo (Kamruzzaman et al., 2008).

The cellulose contents of $Y$. alpina and Dendrocalamopsis oldhami are 46.76 and $45.0 \%$ which lower than the current results of 3 years-old of Giant Timber Bamboo (48.99\%) (Tsegaye et al., 2020). The average cellulose contents of Moso bamboo aged from 1 to 5 years old is $44.64 \%$ which is lower than the current results of 3 years old of Giant Timber Bamboo (48.99\%) (Li et al., 2015).

The average cellulose contents of Bambosa vulgaris species is $50.23 \%$ which higher than the current results of 3 years old of Giant Timber bamboo (48.99\%) (Nahar and Hasan, 2013).

The hemicelluloses content of $Y$. alpina at the ages of 3 years-old is $12.18 \%$ which lower than the current results of 3 years-old of Giant Timber bamboo (19.52\%) (Tsegaye et al., 2020; Nahar and Hasan, 2013).

The average hemicelluloses contents of Moso bamboo and Dendrocalamopsis oldhami are $(23.65 \%)$ similar and (26.1\%) higher compared to the current results of aged from 1 to 3 years old of Giant Timber bamboo (19.52-23.71)\% respectively (Li et al., 2015; Cao et al., 2014).

The average hemicelluloses contents of Bambosa vulgaris bamboo is $16.85 \%$ which lower than the current results of aged from 1 to 3 years old of Giant Timber bamboo (19.52-23.71)\% (Nahar and Hasan, 2013).

The lignin content of $Y$. alpina at the ages of 3 yearsold is $25.27 \%$ which higher than the current results of aged from 1-3 years-old of Giant Timber bamboo (19.43$22.42) \%$ (Tsegaye et al., 2020).

The average lignin contents of Moso and Dendrocalamopsis oldhami bamboo are 20.35 and $20.9 \%$ respectively, which similar compared to the current results of aged from 1-3 years old of Giant Timber bamboo (19.4322.42)\% (Li et al., 2015; Cao et al., 2014).
Average lignin contents of Bambosa vulgaris bamboo is $23.91 \%$ which higher than the current results of aged from 1 to 3 years old of Giant Timber bamboo (19.43-22.42)\% (Nahar and Hasan 2013).

The average extractive contents of Dendrocalamopsis oldhami bamboo is $3.9 \%$ which lower than the current results of aged from 1-3 years old of Giant Timber bamboo (7.45-10.44)\% (Cao et al., 2014).

The ash content of $Y$. alpina at the ages of 3 years-old is $3.77 \%$ which higher than the current results of aged from 1-3 years-old of Giant Timber bamboo (1.87-2.71)\% (Tsegaye et al., 2020).

The ash content of G. atroviolacea bamboo is $3.29 \%$ which higher than the current results of aged from 1-3 years-old of Giant Timber bamboo (1.87-2.71)\%. However, Giant Timber bamboo aged from 1-3 years old is similar the ash content of G. apus and G. levis are 2.45 and $2.46 \%$ respectively, which similar with the current results of aged from 1-3 years old of Giant Timber bamboo (1.87-2.71)\% (Purbasari et al., 2016).

The average lignin contents of Bambosa vulgaris bamboo is $1.38 \%$ which lower than the current results of aged from 1-3 years old of Giant Timber bamboo (1.87-2.71)\% (Nahar and Hasan, 2013).

The ash content of Dendrocalamopsis oldhami bamboo is $1.5 \%$ which lower than the current results of aged from 1-3 years-old of Giant Timber bamboo (1.87-2.71)\% (Cao et al., 2014).

\section{Conclusion}

Giant Timber bamboo in Ethiopia was investigated to characterize their properties based on ages and heights for structural application, industrial purpose and fiberboard production uses. The bamboo plants were harvested in Amhara Region South Wollo at Kombolcha town.

The culm is the highest and largest in diameter of bamboo species in Ethiopia. The height, internodes length, internodes diameter and thickness of the culm are 10.3-12.00 m, 28.8$31.8, \quad 6.3-10.4 \mathrm{~cm}$ and $6.77-8.53 \mathrm{~mm}$ respectively. Depending on the morphological characteristics considered, the length of the internodes is suited for bamboo fiber production, moreover, internodes diameter and culm wall thickness are suited for structural application and furniture making.

Moisture contents of Giant timber bamboo at the ages of 1, 2 and 3 years old are 159.167, 139.0667 and 68.533\%, whereas, along with the culm height at the bottom, middle and top are $143.067,121.767$ and $101.933 \%$ respectively. Shrinkage in wall thickness is lowest at the ages of 3 years old which has good enough dimensional stability.

Depending on the moisture contents and shrinkage in wall thickness considered, age of 3 years old of the culm is suited for structural application and furniture making, but age of 1-year-old of the culm is suited for fiber extraction without damage to the fibers. The existing of water in 
the culm to improve an easy extraction of the fibers from the culm. Basic density of Giant timber bamboo at the ages of 1, 2 and 3 years old are 596.7, 745.4 and $825.7 \mathrm{Kg} / \mathrm{m}^{3}$ respectively.

Considering the age of culm in the basic density, age of 3 years old has been good mechanical strength which could be utilized for building a house, furniture making and structural application. The properties of the culm are evaluated by the percentages of constituents of the chemical on the culm which influence the performance of structural and fibers reinforced composite application.

Cellulose and lignin contents of Giant Timber bamboo increase when the ages of culmolder, whereas ash, extractive and hemicelluloses decrease when the ages of culm older. Celluloses, hemicelluloses, lignin and ash contents increase along with the culm height, but extractive contents decrease along with the culm height.

Depending on the cellulose contents considered, age of 3 years old is suited for biofuel production, fiber production and pulp industry, whereas lignin contents are greatest at the ages of 3 years old which used for astructural application and furniture making. Moreover, hemicelluloses are greatest at the ages of 1-year old which used for the paper factory. Cellulose content of Giant Timber is a greater amount compared to Y. alpina and. It is used for the application area of requiring high celluloses contents like a laminate board, fiberboard and particleboard products.

\section{Acknowledgement}

Researchers want to heartily thanks Dr. Tatek, Dean of, School of Mechanical, Chemical and Materials Engineering and Mr. Mengistu Gelaw, program chair, Department of Mechanical Design and Manufacturing Engineering for their valuable inspiration, encouragement and providing necessary research facilities.

\section{Funding}

All prior investigations in preparation this study were funded by Minister of Science and Higher Education, Addis Ababa, Ethiopia.

\section{Author's Contributions}

Yalew Dessalegn: Proceed the experiment work.

Balkeshwar Singh: Designed the research plan and organized the study.

Aart W. van Vuure: Coordinated the mouse work.

\section{Ethics}

This article is original and contains unpublished material. The corresponding author confirms that all of the other authors have read and approved the manuscript and no ethical issues involved.

\section{References}

Adeeyo, O. A., Oresegun, O. M., \& Oladimeji, T. E. (2015). Compositional analysis of lignocellulosic materials: Evaluation of an economically viable method suitable for woody and non-woody biomass. American Journal of Engineering Research (AJER), 4(4), 14-19. http://eprints.covenantuniversity.edu.ng/5715/

Anokye, R., Kalong, R. M., Bakar, E. S., Ratnasingam, J., Jawaid, M., \& Awang, K. (2014). Variations in moisture content affect the shrinkage of Gigantochloa scortechinii and Bambusa vulgaris at different heights of the bamboo culm. BioResources, 9(4), 7484-7493.

Anwar, U. M. K., Zaidon, A., Hamdan, H., \& Tamizi, M. M. (2005). Physical and mechanical properties of Gigantochloa scortechinii bamboo splits and strips. Journal of Tropical Forest Science, 1-12. https://www.jstor.org/stable/23616523

ASTM. (1997). Standard Test Method for Linear Shrinkage of Preformed High-Temperature Thermal Insulation Subjected to Soaking Heat 1 C 356-87

ASTM. (2004). Standard Test Method for Moisture Absorption Properties and Equilibrium Conditioning of Polymer Matrix Composite Materials. D 5229/D 5229M-92

Azadeh, A., \& Ghavami, K. (2018). The influence of heat on shrinkage and water absorption of Dendrocalamus giganteus bamboo as a functionally graded material. Construction and Building Materials, 186, 145-154. https://doi.org/10.1016/j.conbuildmat.2018.07.011

Banik, R. L. (2015a). "Silviculture of South Asian Priority Bamboos, Tropical Forestry," Springer Science+Business Media Singapore. https://doi.org/10.1007/978-981-10-0569-5_4

Banik, R. L. (2015b). Harvesting Techniques. In Bamboo (pp. 193-226). Springer, Cham. https://doi.org/10.1007/978-3-319-14133-6_7

Benton, A. (2015). Priority species of bamboo. In Bamboo (pp. 31-41). Springer, Cham. https://doi.org/10.1007/978-3-319-14133-6_2

Cao, S., Ma, X., Lin, L., Huang, F., Huang, L., \& Chen, L. (2014). Morphological and chemical characterization of green bamboo (Dendrocalamopsis oldhami (Munro) Keng f.) for dissolving pulp production. BioResources, $9(3)$ 4528-4539. http://ojs.cnr.ncsu.edu/index.php/BioRes/article/view/4 810

Chaowana, P. (2013). Bamboo: An alternative raw material for wood and wood-based composites. Journal of Materials Science Research, 2(2), 90. 
Correal, D., J. F., \& Arbeláez, C., J. (2010). Influence of age and height position on Colombian Guadua angustifolia bamboo mechanical properties. Maderas. Ciencia y Tecnología, 12(2), 105-113. https://scielo.conicyt.cl/scielo.php?pid=S0718221X2010000200005\&script=sci_arttext\&tlng=n

Gebrekidan, S., Tiki, L., \& Mulatu, Y. (2018). Indigenous knowledge on highland bamboo (Yushania alpina) management and utilization practices in Kokosa Woreda, South East Ethiopia. Scientific Research and Essays, 13(11), 111-122.

Gebremariam, Y., \& Assefa, D. (2018). The Effect of Age and Height on Some Selected Physical Properties of Ethiopian Highland Bamboo (Yushania Alpina). International Journal of Scientific Research and Management 6 (08):70-74.

Hisham, H. N., Othman, S., Rokiah, H., Latif, M. A., Ani, S., \& Tamizi, M. M. (2006). Characterization of bamboo Gigantochloa scortechinii at different ages. Journal of Tropical Forest Science, 236-242. https://www.jstor.org/stable/43594680?seq=1

INBAR. (1996). "Bamboo, People and The Environment," Proceedings of the Vth International Bamboo Workshop and the IV International Bamboo Congress Ubud, Bali, Indonesia

Kalali, E. N., Hu, Y., Wang, X., Song, L., \& Xing, W. (2019). Highly-aligned cellulose fibers reinforced epoxy composites derived from bulk natural bamboo. Industrial Crops and Products, 129, 434-439. https://doi.org/10.1016/j.indcrop.2018.11.063

Kamruzzaman, M., Saha, S. K., Bose, A. K., \& Islam, M. N. (2008). Effects of age and height on physical and mechanical properties of bamboo. Journal of Tropical Forest Science, 211-217. https://www.jstor.org/stable/23616502

Kebede, A. A. (2018). Opportunities and Challenges to Highland Bamboo-Based Traditional Handicraft Production, Marketing and Utilization in Awi Zone, Northwestern Ethiopia. International Journal of History and Cultural Studies 4 (4), 57-67. https://www.arcjournals.org/pdfs/ijhcs/v4-i4/5.pdf

Kindu, M., \& Mulatu, Y. (2010). "Status of Bamboo Resource Development, Utilization and Research in Ethiopia : A Review." Ethiopian Journal of Natural Resources 1, 79 - 98.

Koman, S., \& Feher, S. (2015). Basic density of hardwoods depending on age and site. Wood Research, 60(6), 907-912.

Li, X., Sun, C., Zhou, B., \& He, Y. (2015). Determination of hemicellulose, cellulose and lignin in moso bamboo by near infrared spectroscopy. Scientific Reports, $\quad 5(1), \quad 1-11$. https://doi.org/10.1038/srep17210
Liese, W. (1985, October). Anatomy and properties of bamboo. In Proceedings of the International Bamboo Workshop (pp. 196-208). file://C:/Users/WindowS\%2010/Downloads/IDL8719\%20(1).pdf

Mohmod, A. L. Ariffin, W. T. W., \& Ahmad, F. (2016a). Anatomical features and mechanical properties of three Malaysian.

Mohmod, A. L., Amin, A. H. Kasim, J., \& Jusuh, M. Z. (2016b). Effects of anatomical characteristics on the physical and mechanical properties of bambusa blumeana: Published by: Forest Research Institute Malaysia Stable URL. 6 (2), 159-70.

Mulatu, Y., Alemayehu, A., \& Tadesse, Z. (2016). Bamboo species Introduced in Ethiopian.

Nahar, S., \& Hasan, M. (2013). Effect of chemical composition, anatomy and cell wall structure on tensile properties of bamboo fiber. Engineering Journal, 17(1), 61-68. https://doi.org/10.4186/ej.2013.17.1.61

Parameswaran, N., \& Liese, W. (1976). On the Fine structure of Bamboo Fibres. Wood Science and Technology 10, 231-246. https://doi.org/10.1007/BF00350830.

Paudel, S. (2011). Development and Promotion of Bamboo Housing Technology in East Africa. http://www.humanitarianlibrary.org/sites/default/file s/2014/02/IDL-48258.pdf

Pozo Morales, A., Güemes, A., Fernandez-Lopez, A., Carcelen Valero, V., \& De La Rosa Llano, S. (2017). Bamboo-polylactic acid (PLA) composite material for structural applications. Materials, 10(11), 1286. https://doi.org/10.3390/ma10111286

Purbasari, A., Samadhi, T. W., \& Bindar, Y. (2016). Thermal and ash characterization of Indonesian bamboo and its potential for solid fuel and waste valorization. International Journal of Renewable Energy Development, 5(2), 95. https://doi.org/10.14710/ijred.5.2.95-100

Sadiku, N. A., \& Bada, S. O. (2017). Technical rotation age for naturally-grown bambusa vulgaris for fibre, fuel and structural application. Journal of Tropical Forest Science, 541-548. https://doi.org/10.26525/jtfs2017.29.4.541548

Sanquetta, C., Mognon, F., Dalla, A., Maas, G., \& Saquetta, M. (2015). "Survival and Culm Yield of Six Bamboo Species in a 5- Year Experimental Stand in Southern Brazil." X Congreso Mundial Del Bambu, Corea 20151 (Fao 2010): 8.

Thirunirai Selvan, R., Parthiban, K. T., \& Umesh Khanna, S. (2017). Physio-Chemical Properties of Bamboo Genetic Resources at Various Age Gradations. International Journal of Current Microbiology and Applied Sciences, 6 (8), 1671-81. https://doi.org/10.20546/ijcmas.2017.609.205 
Tsegaye, M., Chandravanshi, B. S., Feleke, S., \& Redi, M. (2020). Chemical Composition of Yushania alpina (K. Schum.) WC Lin (1974) (Highland Bamboo) Grown in Ethiopia. World News of Natural Sciences, 32 , https://doi.org/10.1080/17597269.2019.1573608

$1-9$.

Wang, H., Tian, G., Li, W., Ren, D., Zhang, X., \& Yu, Y. (2015). Sensitivity of bamboo fiber longitudinal tensile properties to moisture content variation under the fiber saturation point. Journal of Wood Science, 61(3), 262-269. https://doi.org/10.1007/s10086-015$1466-\mathrm{y}$
Wang, X. Q., Li, X. Z., \& Ren, H. Q. (2010). Variation of microfibril angle and density in moso bamboo (Phyllostachys pubescens). Journal of Tropical Forest Science, 88-96. https://www.jstor.org/stable/23616694

Yu, X. (2008). Bamboo: Structure and Culture. 196. 